\title{
Inflammatory and Cell Adhesion Protein Markers in Colorectal Cancer in Patients Seen at the Teaching Hospital of Guadeloupe: Role of NF kappaB and P-Selectin
}

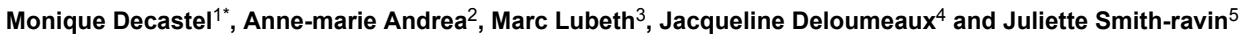 \\ ${ }^{1}$ Inserm UMR_S1134/UAG, University Hospital (CHU) de Pointe-à-Pitre, F-97100, Guadeloupe, France \\ ${ }^{2}$ Department of Pathology, CHU Pointe-à-Pitre, France \\ ${ }^{3}$ Department of Digestive Surgery, CHU Pointe-à-Pitre, France \\ ${ }^{4}$ Cancer Registry of Guadeloupe, $\mathrm{CHU}$ de Pointe-à-Pitre, France \\ ${ }^{5}$ Scientific Department Interfacultaire, University of the Antilles and Guyana, EA929 AIHP-GEODE (BIOSPHERES), Schœ/cher Campus, Martinique, F-97200 France
}

*Corresponding author: Monique Decastel, UMR Inserm_S1134, CNRS SNC 9169, CHU de Pointe-à-Pitre, bâtiment Ricou, 97159 Guadeloupe, France, Tel: +33 (0)590 8348 99; Fax: +33 (0)590 8305 13; E-mail: moniquedecastel@yahoo.fr; monique.decastel@inserm.fr

Rec date: Jun 17, 2014, Acc date: Aug 29, 2014, Pub date: Sep 01, 2014

Copyright: ( 2014 Decastel M, et al. This is an open-access article distributed under the terms of the Creative Commons Attribution License, which permits unrestricted use, distribution, and reproduction in any medium, provided the original author and source are credited.

\begin{abstract}
Background: Previous reports have been published describing the role of protein markers in the development and progression of colorectal cancers (CRC). In those investigations, Nuclear Factor kappaB (NFKB) and the

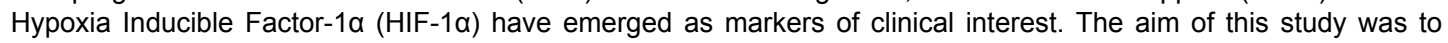
evaluate their expression in patients who underwent surgery for CRC in the Guadeloupe Teaching Hospital (GlpeTH).

Methods: Tumour tissues and the normal mucosa from 67 patients of GlpeTH were immunohistochemically evaluated using antibodies against HIF-1 $\alpha$ and NFKBp65. Additionally; we examined the expression of Vascular Endothelial Growth factor (VEGF), Vascular Cell Adhesion Molecule-1 (VCAM-1) and P-selectin, which was regulated by HIF-1 $\alpha$ and NFKBp65, respectively.

Results: Expression of NFKBp65 and HIF-1a, mainly located in the cytoplasm of the cancer cells and P-selectin, located on endothelial cells of blood vessels, was positively observed in $74.6 \%, 73.1 \%$ and $23.9 \%$ among the patients, respectively. Unexpectedly, expression of VEGF and VCAM-1 was weak, $6 \%$ and $3 \%$ respectively. HIF-1a did not associate either with clinicopathological parameters or NFKBp65 expression, whereas the latter significantly did with invasion depth $(p=0.017)$. Regarding P-selectin, its expression was not correlated with that of NFKBp65, but significantly was with TNM stage $(p=0.022)$.
\end{abstract}

Conclusion: Expression of VEGF and VCAM-1 may depend of other tumour environmental factors. NFKB, more frequently expressed in T3-T4 stages and P-selectin less in aggressive CRCs (TNM III and IV) are more valuable protein markers than HIF-1 $\alpha$, to characterize CRC in GlpeTH patients.

Keywords: Colorectal cancer; Guadeloupe teaching hospital; Nuclear factor kappaB; P-selectin; TNM
Abbreviations
CRC: Colorectal Cancer; GlpeTH: Guadeloupe Teaching Hospital, NFкB: Nuclear Factor kappa B; VEGF: Vascular Endothelial Growth Factor; VCAM-1: Vascular Cell Adhesion Molecule-1; HIF-1a: Hypoxia Inducible Factor-1 alpha; IHC: Immunohistochemistry; TNM: Tumour Node Metastasis

\section{Introduction}
The aetiology of colorectal cancer (CRC) is complex, developing through a series of progressive changes defined by clinical and histopathological parameters [1,2]. In this regard, several reports have been published describing the roles of markers involved in progression and development of CRC [3-11]. In those investigations the

transcription factors HIF-1 and NFkB have emerged as markers of significant clinical interest [3,5,7,9-11]. HIF-1, which is considered the master regulator of the hypoxic response in normal cells, is composed of a constitutively expressed $\beta$ subunit and a hypoxia-induced $\alpha$ subunit rapidly degraded under normoxic conditions [12]. Its overexpression is associated with tumour angiogenesis and invasion in CRC [5]. HIF-1a is also reported to be the main activator of VEGF [13] which plays an essential role in tumour development and correlates with progression and metastatic process [14]. NF- $\kappa B$, which also plays a key role in the regulation of cell death, cell viability and inflammation, consists of two major polypeptides, p50 and p65 [15]. In tumour cells, activation of the p65 subunit induces the development and progression of cancer $[3,9]$. NFKB activates not only VEGF expression but also increases that of vascular cell adhesion molecule-1 (VCAM-1) and P-selectin, both involved in inflammation, but also in cancer proliferation, invasion and the metastatic process [15]. 
Citation: Decastel M, Andrea A, Lubeth M, Deloumeaux J, Smith-ravin J (2014) Inflammatory and Cell Adhesion Protein Markers in Colorectal Cancer in Patients Seen at the Teaching Hospital of Guadeloupe: Role of NF kappaB and P-Selectin. J Cytol Histol 5: 276. doi: $10.4172 / 2157-7099.1000276$

Page 2 of 5

Colorectal cancer in Guadeloupe, one of the two French overseas regions in the Caribbean, is becoming a serious public health problem. Indeed, the incidence of CRC has increased five-fold in 25 years. The main factors for this increase are not known, but may be due to changes in dietary habits, multiplicity in genetic profiles and/or to environmental exposures. We recently describe the clinicopathological characteristics of CRC in patients who underwent surgery in the GlpeTH between 1995 and 2000 [16]. Nevertheless, data on the expressions of NFKB, HIF-1 $\alpha$, VEGF, VCAM- 1 and P-selectin in these patients are lacking.

The aim of the present study was to investigate whether the five markers cited above are expressed in patients operated for CRC in the GlpeTH. We additionally studied whether their expressions were correlated and or associated with the clinicopathological features.

\section{Materials and Methods}

\section{Tissue samples and patient information}

Archival formalin-fixed and paraffin-embedded tumour tissues and normal mucosa, taken 5 centimetres away from the tumour area, were chosen among patients who underwent surgery in the GlpeTH between 1995 and 2000 [16]. None of the patient recruited to the study received chemotherapy or radiotherapy prior tumour resection. The present, descriptive retrospective study was approved by the local Ethical Committee of the GlpeTH (Advisory Committee on protection in Biomedical Research: project 2-2007-(bis). Histological type, tumour grade and tumour stage were determined according to the WHO and TNM classification systems. Haematoxilin \& Eosin stained slides were reviewed by two pathologists from GlpeTH to evaluate the patterns and intensity of the five markers using a light microscope (Zeiss).

The study involved 67 patients, 57\% were males and $43 \%$ were females with a mean age of 68 years. $95 \%$ were adenocarcinomas and $5 \%$ mucinous adenocarcinomas. The sigmoid colon was the most common sites of tumour (36\%). Moderately differentiated tumour represented 51\%, TNM stages II and III represented $48 \%$ and $43 \%$, respectively and $43 \%$ had lymph node metastases.

\section{Immunohistochemistry (IHC)}

Expression of proteins was assessed by IHC using the Horseradish detection system EnVision kit plus Dual link system-HRP complex and anti-Mouse/Rabbit-HRP (DAKO, Carpinteria, CA, USA) as recently described [16]. The following primary antibodies: rabbit polyclonal antibody raised against HIF-1a (H 2061; dilution 1:50; Santa Cruz Biotechnology, Santa Cruz, CA, USA), rabbit polyclonal antibody against NFKB p65 (sc-109; dilution 1:100; Santa Cruz Biotechnology), mouse monoclonal antibody against VEGF (VG1; dilution 1:25; DAKO), which labels the VEGF-121, VEGF-165 and VEGF-189, mouse monoclonal antibody to VCAM-1 (1:25 dilution; clone $1.4 \mathrm{C} 3, \mathrm{DAKO}$ ) and mouse monoclonal antibody against Pselectin (M7199; dilution 1:25; DAKO), were used. Note that conditions for each antibody were as described by the manufacturer. Staining without the primary antibody was done as a negative control. Nuclei were counterstained with haematoxylin and slides mounted for examination. The following four-grade scoring system, as recently described [16] was used: (0) no reaction; $\left(1^{+}\right)$weak reaction; $\left(2^{+}\right)$ moderate reaction and $\left(3^{+}\right)$strong reaction.

\section{Statistical analysis}

Analyses were performed using the Statistical Package for the Social Science (SPSS) computer software version 17.0 (IBM SPSS Statistics, Chicago, IL, USA). The Chi-square test or Fisher's exact test was used when appropriate, for comparing categorical variables (contingency tables). Various typical prognostic factors were considered for univariate analysis. Correlations between markers were calculated by Spearman rank correlation. In all cases, a p value less than 0.05 was considered statistically significant.

\section{Results}

\section{Immunohistochemical expression of NFKB, HIF-1a, VEGF, VCAM-1 and P-selectin}

We did not find any staining in the adjacent normal colonic tissues collected from the same subjects whatever the antibodies used (Figure 1A). On the contrary, HIF-1astaining was mainly located in the cytoplasm of the cancer cells (Figure 1B), although very few cells showed nuclear staining (Figure $1 \mathrm{~B}$, arrow). The staining was positive in 49 of the 67 CRCs (73.1\%) (Figure 2), 40 being weakly positive, 7 moderately positive and 2 highly positive.

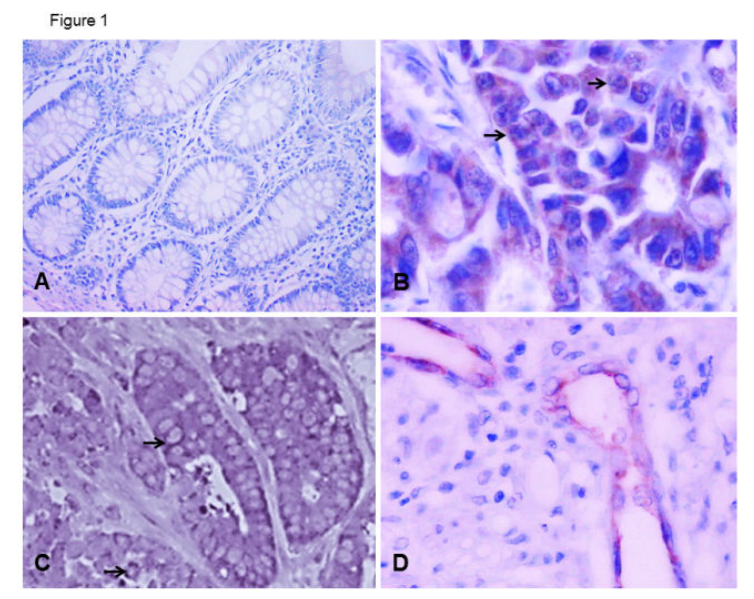

Figure 1: Representative examples of immunohistochemical staining patterns of HIF- $1 \alpha, \mathrm{NF \kappa B}$ and P-selectin. A: Normal tissue counterpart shows absence of staining (magnification x 200). B: moderate cytoplasmic HIF-1a staining in a well differentiated tumour (magnification x 400). Very few cells exhibit nuclear staining (arrows). C: Moderate cytoplasmic NFkB staining in a differentiated tumour (magnification $\mathrm{x}$ 400). One cell shows nucleus staining (arrow). D: Endothelial cells of the tumour associated blood vessels stained for P-selectin are observed in a poorly differentiated tumour (magnification x 400). Haematoxylin counterstained.

NFkBp65 staining was also detected in the cytoplasm of the cancer cells (Figure 1C), although very rare cells showed also a nuclear staining (Figure 1C, arrow). The staining was positive in 48 of the 67 CRCs (71.6\%) (Figure 2); among the positive cases, 2 were highly positive, 32 moderately positive and 14 weakly positive. Unexpectedly, very few cells were weakly positive for VEGF-A (5.9\%, 4 cases) and 
Citation: Decastel M, Andrea A, Lubeth M, Deloumeaux J, Smith-ravin J (2014) Inflammatory and Cell Adhesion Protein Markers in Colorectal Cancer in Patients Seen at the Teaching Hospital of Guadeloupe: Role of NF kappaB and P-Selectin. J Cytol Histol 5: 276. doi:

Page 3 of 5

VCAM-1 (2.9\%, 2 cases) (Figure 2). Finally, P-selectin staining was detected at the surface of the endothelial cells (Figure 1D) and was positive in $18(23.9 \%)$ of the 67 CRCs (Figure 2), 10 being weakly positive and 8 moderately positive.

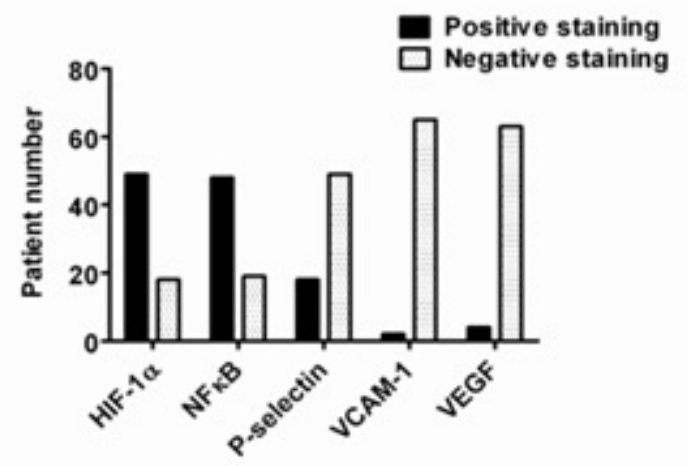

Figure 2: Number of CRC patients stained with HIF-1a, NFkB, Pselectin, VCAM-1 and VEGF. Data are given as number of positive and negative CRCs.

\section{Association between markers and with clinicopathological parameters}

As indicated in Table 1, there was no correlation between NFkBp65 and HIF-1 $\alpha(\mathrm{p}=0.75)$ or between NFkBp65and P-selectin $(\mathrm{p}=0.76)$ or between HIF-1 $\alpha$ and P-selectin $(p=0.36)$ using Fisher's exact test. Spearman correlation strengthened these later results. Indeed, NFkBp65 was neither correlated with P-selectin $(r=-0.039 ; \mathrm{p}=0.75)$ or HIF- $1 \alpha(r=0.091 ; p=0.46)$; likewise the latter was not correlated with Pselectin $(\mathrm{r}=-0.082 ; \mathrm{p}=0.51)$. On the opposite, Table 2 indicates that NFkBp65 positivity significantly associated with $\mathrm{pT}$ stage, $(\mathrm{p}=0.017)$, although males tended to be more frequently NFkBp65 positive (81.6\%) than females (58.6\%). Regarding HIF-1a, there was no significant association between its positive accumulation and any of the clinicopathological variables evaluated $(\mathrm{p}>0.05)$ (Table 1). Pselectin expression significantly associated with pTNM stage $(\mathrm{p}=0.022)$ and CRCs diagnosed without regional lymph node metastasis having a great tendency to be $\mathrm{P}$ selectin positive (36.8\%; $\mathrm{p}=0.051)$.

\begin{tabular}{|c|c|c|c|c|c|c|}
\hline & \multicolumn{2}{|l|}{ NFKB } & \multirow[t]{2}{*}{$p$} & \multicolumn{2}{|c|}{ HIF-1 $\alpha$} & \multirow[t]{3}{*}{$\mathbf{p}$} \\
\hline & $(+)$ & $(-)$ & & $(+)$ & $(-)$ & \\
\hline & $n=48$ & $n=19$ & & $n=49$ & $n=18$ & \\
\hline P-selectin & & & 0.76 & & & 0.36 \\
\hline$(+) n=18$ & 12 & 6 & & 15 & 3 & \\
\hline$(-) n=49$ & 36 & 13 & & 34 & 15 & \\
\hline HIF-1 & & & 0.75 & & & \\
\hline$(+) n=49$ & 35 & 15 & & & & \\
\hline (-) $n=18$ & 13 & 4 & & & & \\
\hline
\end{tabular}

NFKB, nuclear factor kappaB; HIF-1 1 , hypoxia-inducible factor-1 alpha. Lack of association between markers was obtained using the Fisher's exact test.

Table 1: Lack of correlation between NFkB, HIF-1 $\alpha$ and P-selectin

\begin{tabular}{|c|c|c|c|c|c|c|c|}
\hline Parameters & $\mathbf{N}$ & $\begin{array}{l}\text { NFKB } \\
n(\%)\end{array}$ & p & $\begin{array}{l}\text { HIF-1 } \\
\text { n (\%) }\end{array}$ & $\mathbf{p}$ & $\begin{array}{l}\text { P- } \\
\text { selecti } \\
\text { n } \\
\text { n (\%) }\end{array}$ & p \\
\hline Total number & 67 & $\begin{array}{l}48 \\
(71.6)\end{array}$ & & $\begin{array}{l}49 \\
(73.1)\end{array}$ & & $\begin{array}{l}18 \\
(23.9)\end{array}$ & \\
\hline Age & \multirow[t]{2}{*}{26} & \multirow{2}{*}{$\begin{array}{l}17 \\
(65.4)\end{array}$} & \multirow[t]{3}{*}{0.41} & 18 & \multirow[t]{3}{*}{0.58} & 6 & \multirow[t]{3}{*}{0.78} \\
\hline$<68$ years & & & & & & & \\
\hline$\geq 68$ years & 41 & $\begin{array}{l}31 \\
(75.6)\end{array}$ & & $\begin{array}{l}31 \\
(75.6)\end{array}$ & & $\begin{array}{l}12 \\
(26.3)\end{array}$ & \\
\hline Sex & & & 0.056 & & 0.78 & & 0.17 \\
\hline Male & 38 & $\begin{array}{l}31 \\
(81.6)\end{array}$ & & $\begin{array}{l}27 \\
(71.0)\end{array}$ & & $\begin{array}{l}7 \\
(18.4)\end{array}$ & \\
\hline Female & 29 & $\begin{array}{l}17 \\
(58.6)\end{array}$ & & $\begin{array}{l}22 \\
(75.9)\end{array}$ & & $\begin{array}{l}11 \\
(37.9)\end{array}$ & \\
\hline Tumour site & & & 0.11 & & 0.24 & & 0.67 \\
\hline $\begin{array}{l}\text { Colon } \quad(R+L \\
+T)\end{array}$ & 34 & $\begin{array}{l}27 \\
(79.4)\end{array}$ & & $\begin{array}{l}24 \\
(70.6)\end{array}$ & & $\begin{array}{l}8 \\
(23.5)\end{array}$ & \\
\hline sigmoid & 24 & $\begin{array}{l}17 \\
(70.8)\end{array}$ & & $\begin{array}{l}20 \\
(83.3)\end{array}$ & & $\begin{array}{l}8 \\
(33.3)\end{array}$ & \\
\hline Rectum & 9 & $\begin{array}{l}4 \\
(44.4)\end{array}$ & & $\begin{array}{l}5 \\
(55.5)\end{array}$ & & $\begin{array}{l}2 \\
(22.2)\end{array}$ & \\
\hline $\begin{array}{l}\text { Tumour } \\
\text { grade }\end{array}$ & & & 0.57 & & 0.066 & & 0.81 \\
\hline Well D & 26 & $\begin{array}{l}20 \\
(76.9)\end{array}$ & & $\begin{array}{l}19 \\
(73.1)\end{array}$ & & $\begin{array}{l}8 \\
(30.8)\end{array}$ & \\
\hline Moderately D & 34 & $\begin{array}{l}23 \\
(67.6)\end{array}$ & & $\begin{array}{l}27 \\
(79.4)\end{array}$ & & $\begin{array}{l}8 \\
(23.5)\end{array}$ & \\
\hline Poorly D & 4 & $\begin{array}{l}3 \\
(75.0)\end{array}$ & & $\begin{array}{l}1 \\
(25.0)\end{array}$ & & $\begin{array}{l}1 \\
(25.0)\end{array}$ & \\
\hline pTNM Stage & & & 0.082 & & 0.45 & & 0.022 \\
\hline I & 6 & $\begin{array}{l}2 \\
(33.3)\end{array}$ & & $\begin{array}{l}5 \\
(83.4)\end{array}$ & & $\begin{array}{l}4 \\
(66.7)\end{array}$ & \\
\hline II & 32 & $\begin{array}{l}25 \\
(78.1)\end{array}$ & & $\begin{array}{l}25 \\
(78.1)\end{array}$ & & $\begin{array}{l}10 \\
(31.2)\end{array}$ & \\
\hline III+IV & 29 & $\begin{array}{l}21 \\
(72.4)\end{array}$ & & $\begin{array}{l}19 \\
(65.5)\end{array}$ & & $\begin{array}{l}4 \\
(13.8)\end{array}$ & \\
\hline pT stage & & & 0.017 & & 0.79 & & 0.24 \\
\hline $\mathrm{T} 1+\mathrm{T} 2$ & 7 & $\begin{array}{l}2 \\
(28.6)\end{array}$ & & $\begin{array}{l}5 \\
(71.4)\end{array}$ & & $\begin{array}{l}4 \\
(57.1)\end{array}$ & \\
\hline T3 & 45 & $\begin{array}{l}33 \\
(73.3)\end{array}$ & & $\begin{array}{l}34 \\
(75.5)\end{array}$ & & $\begin{array}{l}11 \\
(24.4)\end{array}$ & \\
\hline T4 & 15 & $\begin{array}{l}13 \\
(86.7)\end{array}$ & & $\begin{array}{l}10 \\
(66.7)\end{array}$ & & $\begin{array}{l}3 \\
(20.0)\end{array}$ & \\
\hline pN stage & & & 1.0 & & 0.27 & & 0.051 \\
\hline
\end{tabular}


Citation: Decastel M, Andrea A, Lubeth M, Deloumeaux J, Smith-ravin J (2014) Inflammatory and Cell Adhesion Protein Markers in Colorectal Cancer in Patients Seen at the Teaching Hospital of Guadeloupe: Role of NF kappaB and P-Selectin. J Cytol Histol 5: 276. doi: 10.4172/2157-7099.1000276

Page 4 of 5

\begin{tabular}{|l|l|l|l|l|l|l|l|}
\hline $\begin{array}{l}\text { Node } \\
\text { negative }\end{array}$ & 38 & $\begin{array}{l}27 \\
(71.0)\end{array}$ & & $\begin{array}{l}30 \\
(78.9)\end{array}$ & $\begin{array}{l}14 \\
(36.8)\end{array}$ & \\
\hline Node positive & 29 & $\begin{array}{l}21 \\
(72.4)\end{array}$ & & $\begin{array}{l}19 \\
(65.5)\end{array}$ & $\begin{array}{l}4 \\
(13.8)\end{array}$ & \\
\hline
\end{tabular}

Expression was assessed by immunohistochemistry. Data are given as positive cases and percentage (in brackets) based on N. Association between markers and clinicopathological data was obtained using the Chi-square test or Fisher's exact test. D: differentiated; in bold significant $p$ values.

Table 2: Association between marker positive expression and clinicopathology

\section{Discussion}

In the current study, we demonstrated that HIF-1 $\alpha$, NFkBp65, and P-selectin are expressed in the CRCs of the GlpeTH patients, the two former proteins being detected in the cytoplasm of the cancer cells and the latter on the surface of the endothelial cells. On the opposite, very few cells are positive for VCAM-1 and VEGF. To the best of our knowledge, such study has not been done in these Guadeloupian patients.

When IHC was performed using the respective antibodies we demonstrated that equivalent proportions of CRCs were positive for

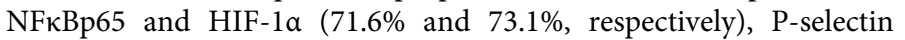
positivity being $23.9 \%$. These values are in good agreement with the previous reports [4-10], but our staining was found moderate in intensity and cytoplasmic for the two formers, corresponding to the inactive forms. Interestingly, a part of our results was in accordance with those obtained by Wincewicz et al. [17] who demonstrate only a cytoplasmic staining, Baltaziak et al. [18] and Maihöfner et al. [19] who demonstrate both cytoplasmic and nuclear staining for NFkBp65 and HIF-1a. Since the nuclear location is believed to be equivalent to activation, we hypothesize an absence of transcriptional activity for HIF-1 $\alpha$ and NFkBp65, probably due to absence of hypoxic area $[7,10]$. This later observation may explain, in part, why VEGF (4 positive cases) and VCAM-1 (2 positive cases) were very weakly detected. However, it is important to note that the two corresponding antibodies work very well when they were used to study VEGF and VCAM-1 expression after stimulation of HUVEC by TNF-alpha an important upstream activator of NFkB signalling pathway (Decastel, unpublished data). Takahashi et al. [20] demonstrate that VEGF expression was greater in colon tumours that have metastasized than in nonmetastatic tumours. Likewise, Wang et al. [21] indicate that other physiological stress in the tumour environment can induce VEGF expression. Furthermore, the soluble form has been observed in many neoplasms including colon cancer [22]. Regarding VCAM-1, whose expression is stimulated by TNF-alpha, its soluble form has also been observed in many neoplasms including colon cancer [22]. It could be the case in the present study, since only one tumour was detected at TNM IV and any measurement of sVCAM-1 and sVEGF was performed in the plasma of the Glpe TH patients.

We further studied association with clinicopathological parameters. Any correlation was found between HIF-1a and the clinical parameters as previously observed in CRC $[11,17]$. Interestingly, expression of NFkBp65 significantly increased with depth of invasion $(\mathrm{p}=0.017)$, in accordance with previous data [17-19] which related cytoplasmic staining with cancer progression. Inversely, P-selectin expression significantly decreased with the CRC aggressiveness (TNM stages III and IV). This later result correlated well with the previous one of Peeters et al. [4] who demonstrate that in CRC malignant progression of the tumour leads to progressive P-selectin down regulation. It could be the case in the present study.

\section{Conclusion}

This retrospective, descriptive study has enabled us to evaluate, in Guadeloupian CRC patients, expression of proteins involved either in the pathogeneses of inflammation, or hypoxia, or angiogenesis or metastasis [15,23-25]. The combined use of different markers could be more valuable to detect CRC aggressiveness in patients. The role of protein markers in CRC is controversial. Even if our study is limited due to its small size, it contributes to the debate. Indeed, we proposed that VEGF and VCAM-1 expression may depend of tumour environmental factors [21] distinct from NFkBp65 and HIF-1a. In addition, regarding CRC p53 expression, we recently demonstrate differences between Glpe TH patients and Martinique Teaching hospital patients, as well as metropolitan France and Caucasian patients [16]. Thus, the differential expression of the five markers tested in the present study may be related to the multiplicity of genetic profile of the GlpeTH patients.

\section{Acknowledgements}

This work is partially supported by the Academic Hospital of Guadeloupe: Hospital Program of Clinical Research and "Région Guadeloupe": Contrat Plan Etat /Région (2000-2006). The authors would like to thank Dr. Anne MARREEL and Maryline LeTHEO for helpful comments.

\section{References}

1. Vogelstein B, Fearon ER, Hamilton SR, Kern SE, Preisinger AC, et al. (1988) Genetic alterations during colorectal-tumor development. N Engl J Med 319: 525-532.

2. Jass JR (2007) Classification of colorectal cancer based on correlation of clinical, morphological and molecular features. Histopathology 50: 113-130.

3. Shishodia S, Aggarwal BB (2004) Nuclear factor-kappaB: a friend or a foe in cancer? Biochem Pharmacol 68: 1071-1080.

4. Peeters CF, Ruers TJ, Westphal JR, de Waal RM (2005) Progressive loss of endothelial P-selectin expression with increasing malignancy in colorectal cancer. Lab Invest 85: 248-256.

5. Furlan D, Sahnane N, Carnevali I, Cerutti R, Uccella S, et al. (2007) Upregulation and stabilization of HIF-1alpha in colorectal carcinomas. Surg Oncol 16 Suppl 1: 25-27.

6. Kobayashi H, Boelte KC, Lin PC (2007) Endothelial cell adhesion molecules and cancer progression. Curr Med Chem 14: 377-386.

7. Greijer AE, Delis-van Diemen PM, Fijneman RJ, Giles RH, Voest EE, et al. (2008) Presence of HIF-1 and related genes in normal mucosa, adenomas and carcinomas of the colorectum. Virchows Arch 452: 535-544.

8. Zafirellis K, Agrogiannis G, Zachaki A, Gravani K, Karameris A, et al. (2008) Prognostic significance of VEGF expression evaluated by quantitative immunohistochemical analysis in colorectal cancer. J Surg Res 147: 99-107.

9. Sakamoto K, Maeda S, Hikiba Y, Nakagawa H, Hayakawa Y, et al. (2009) Constitutive NF-kappaB activation in colorectal carcinoma plays a key role in angiogenesis, promoting tumor growth. Clin Cancer Res 15: 2248-2258.

10. Cao D, Hou M, Guan YS, Jiang M, Yang Y, et al. (2009) Expression of HIF-1alpha and VEGF in colorectal cancer: association with clinical outcomes and prognostic implications. BMC Cancer 9: 432. 
Citation: Decastel M, Andrea A, Lubeth M, Deloumeaux J, Smith-ravin J (2014) Inflammatory and Cell Adhesion Protein Markers in Colorectal Cancer in Patients Seen at the Teaching Hospital of Guadeloupe: Role of NF kappaB and P-Selectin. J Cytol Histol 5: 276. doi: $10.4172 / 2157-7099.1000276$

Page 5 of 5

11. Kwon HC, Kim SH, Oh SY, Lee S, Kwon KA, et al. (2010) Clinicopathological significance of nuclear factor-kappa B, HIF-1 alpha, and vascular endothelial growth factor expression in stage III colorectal cancer. Cancer Sci 101: 1557-1561.

12. Wang GL, Jiang BH, Rue EA, Semenza GL (1995) Hypoxia-inducible factor 1 is a basic-helix-loop-helix-PAS heterodimer regulated by cellular O2 tension. Proc Natl Acad Sci U S A 92: 5510-5514.

13. Ratcliffe PJ, O'Rourke JF, Maxwell PH, Pugh CW (1998) Oxygen sensing, hypoxia-inducible factor- 1 and the regulation of mammalian gene expression. J Exp Biol 201: 1153-1162.

14. Ferrara N (2004) Vascular endothelial growth factor: basic science and clinical progress. Endocr Rev 25: 581-611.

15. De Martin R, Hoeth M, Hofer-Warbinek R, Schmid JA (2000) The transcription factor NF-kappa $\mathrm{B}$ and the regulation of vascular cell function. Arterioscler Thromb Vasc Biol 20: 83-88.

16. Decastel M, Ossondo M, Andrea AM, Tressieres B, Veronique-Baudin J, et al. (2014) Colorectal cancer in patients seen at the teaching hospitals of Guadeloupe and Martinique: discrepancies, similarities in clinicopathological features, and p53 status. BMC Clin Pathol 14: 12.

17. Wincewicz A, Sulkowska M, Koda M, Sulkowski S (2007) Clinicopathological significance and linkage of the distribution of HIF-1alpha and GLUT-1 in human primary colorectal cancer. Pathol Oncol Res 13: 15-20.

18. Baltaziak M, Wincewicz A, Kanczuga-Koda L, Lotowska JM, Koda M, et al. (2013) The relationships between Hypoxia-dependent markers:
HIF-1alpha, EPO and EPOR in colorectal cancer. Folia Histochem Cytobiol 51: 320-325.

19. Maihöfner C, Charalambous MP, Bhambra U, Lightfoot T, Geisslinger G, et al. (2003) Expression of cyclooxygenase-2 parallels expression of interleukin-1beta, interleukin-6 and NF-kappaB in human colorectal cancer. Carcinogenesis 24: 665-671.

20. Takahashi Y, Kitadai Y, Bucana CD, Cleary KR, Ellis LM (1995) Expression of Vascular Endothelial Growth Factor and Its Receptor, KDR, Correlates with Vascularity, Metastasis, and Proliferation of Human Colon Cancer. Cancer Res 55: 3964-3968.

21. Wang F, Xu P, Xie KC, Chen XF, Li CY, et al. (2013) Effects of tumor microenviromental factors on VEGF expression. Biomed Rep 1: 539-544.

22. Dymicka-Piekarska V, Guzinska-Ustymowicz K, Kuklinski A, Kemona H (2012) Prognostic significance of adhesion molecules (sICAM-1, sVCAM-1) and VEGF in colorectal cancer patients. Thromb Res 129: 47-50.

23. Tak PP, Firestein GS (2001) NF-kappaB: a key role in inflammatory diseases. J Clin Invest 107: 7-11.

24. Angelo LS, Kurzrock R (2007) Vascular endothelial growth factor and its relationship to inflammatory mediators. Clin Cancer Res 13: 2825-2830.

25. Eltzschig HK, Carmeliet P (2011) Hypoxia and inflammation. N Engl J Med 364: 656-665. 